\title{
Chemical Control of Rhynchosia capitata (Roth.) DC in Green Gram with Lactofen at Reduced Rate with Alkyl Ether Sulfate as Adjuvant
}

\author{
Muhammad Ehsan Safdar ${ }^{*}$, Samra Ammara1, Muhammad Sikander Hayyat ${ }^{1}$, Shahbaz Hussain ${ }^{2}$, \\ Muhammad Mansoor Javaid ${ }^{1}$, Abdul Rehman ${ }^{1}$ and Amjed Ali ${ }^{1}$
}

${ }^{1}$ Department of Agronomy, College of Agriculture, University of Sargodha, Sargodha-Punjab 40100, Pakistan; ${ }^{2}$ PARC Rice Program, Kala Shah Kaku, Lahore, Pakistan.

Abstract | A trial was undertaken to ascertain the efficacy of lactofen keeping its full and minimized application rates on Rhynchosia capitata (Roth.) DC in green gram alone and in tank mixed addition of adjuvant (alkyl ether sulfate) at Research Area, University of Sargodha during spring 2015. The studies consisted of seven herbicide treatments, viz. lactofen complete dose $\left(180 \mathrm{~g}\right.$ a.i. ha $\left.{ }^{-1}\right)$ alone, lactofen complete dose + adjuvant, lactofen $80 \%$ dose alone, lactofen $80 \%$ dose + adjuvant, lactofen $60 \%$ dose alone, lactofen $60 \%$ dose + adjuvant and a control (no herbicide). It was found that lactofen full dose with and without adjuvant attained significantly the lowest $R$. capitata dry weight and highest seed yield of green gram. However, these treatments remained statistically at par with lactofen $80 \%$ and lactofen $60 \%$ doses with adjuvant regarding these parameters. Keeping in view the $R$. capitata weed control efficiency along with green gram yield enhancement, it was concluded that lactofen dose can be reduced up to $20-40 \%$ by the addition of adjuvant (alkyl ether sulfate) for management of $R$. capitata in green gram crop.

Received | July 10, 2018; Accepted | July 07, 2021; Published | August 21, 2021

*Correspondence | Muhammad Ehsan Safdar, Department of Agronomy, College of Agriculture, University of Sargodha, Sargodha-Punjab 40100, Pakistan; Email: ehsan_safdar2002@yahoo.com

Citation | Safdar, M.E., S. Ammara, M.S. Hayyat, S. Hussain, M.M. Javaid, A. Rehman and A. Ali. 2021. Chemical control of Rhynchosia capitata (roth.) DC in green gram with lactofen at reduced rate with alkyl ether sulfate as adjuvant. Pakistan Journal of Agricultural Research, 34(4): 706-712.

DOI | https://dx.doi.org/10.17582/journal.pjar/2021/34.4.706.712

Keywords | Alkyl ether sulphate, Rhynchosia capitata, Vigna radiata, Weeds control, Yield

\section{Introduction}

A mong all the legumes, green gram [Vigna radiata (L.) Wilczek] being a short duration and drought tolerant crop can easily be adjusted in each cropping system (Naeem et al., 1999). It is ranked $3^{\text {rd }}$ most important pulse after chickpea and pigeon pea in Pakistan and grown both under irrigated and rain fed conditions. The total area of Pakistan under green gram cultivation is 186.7 thousand hectares and 132.7 thousand tons of total seed production with an average seed yield of $774.7 \mathrm{~kg} \mathrm{ha} \mathrm{h}^{-1}$ (GoP, 2020). The national production of pulses including green gram in Pakistan is quite less than total requirement (Ullah et al., 2020). The major hindrances in achieving higher yield of green gram include inappropriate sowing methods, sub-optimal fertilizer application, sowing on marginal land area, and severe weed infestation.

The poor weed control is the main reason of low seed yield of green gram in Pakistan. Yield losses vary from 65 to $79 \%$ due to weeds infestation in green gram (Dungarwal et al., 2003) depending upon the density, type and competition duration of weeds, time of sowing and methods of sowing, techniques of fertilizer application, availability of water and growing conditions (Mansoor et al., 2004; Arshad et al., 2008). Weeds are responsible for reduction of crop yield, 
crop quality and nutrient status of the soil. Important weeds of green gram are Trianthema portulacastrum, Sorghum halepense, Cyperus rotundus, Digera arvensis, Cynodon dactylon and Echinochloa colona. Rhynchosia capitata (Roth) DC is a new problematic weed of green gram from family Fabaceae and largely scattered in most part of the world. It is an annual weed of summer season that has invaded the crops in the Southern Punjab of Pakistan and has become a threatening weed flora (Ali et al., 2011). It is a jointing prostrate plant having number of branches that spread around the whole rootstock. After a month of seed germination, flowering starts and the plant has elliptical shaped two-seeded pods (Sharma et al., 1978). This weed prevails from May to October and thrives best in average rainfall of $650 \mathrm{~mm}$ over diurnal temperature range of 29 to $39^{\circ} \mathrm{C}$ and 21 to $29^{\circ} \mathrm{C}$, respectively (Ali et al., 2011).

There are various categories of weed control methods including cultural and physical methods, chemical and biological methods. The herbicidal weed control is most suitable due to its promising results and the highest feasibility. Herbicides efficiently decrease the density of weed plants in crops in a relatively shorter period of time (Radosevich et al., 2007). However, use of herbicides involves risks as these may be hazardous to the crop, environment and health. This is especially true when using a new herbicide against a new weed without keeping in view its dose. Similar is the case with $R$. capitata, very little is known about the chemical control of this weed in green gram. Therefore, there is an urge for developing an effective control of $R$. capitata in green gram. Herbicide application rate should be reduced to level at which it can show the lowest phytotoxic effect on crop and environment. The use of adjuvant may be a viable option in this regard. An adjuvant is any substance that is mixed with herbicide to enhance its effectiveness (Hess and Foy, 2000). In some circumstances, efficiency of herbicide in terms of its toxicity against targeted species with little or no destructive effect on nearby plants i.e. selectivity may be increased by the use of adjuvants (Hess and Foy, 2000).

Lactofen herbicide belongs to chemical class diphenyl ether that targets protoporphyrinogen oxidase (PPO), an enzyme of the porphyrin biosynthetic pathway within the chloroplast (Matringe et al., 1989). The suppression of PPO caused the gathering of protoporphyrin IX, a substrate of PPO at the outer of the chloroplast (Lehnen et al., 1990) followed by its photo-oxidation and subsequent lipid peroxidation, specifically on all membranes of cells ultimately cell death (Hess, 2000). Alkyl ether sulphate is an ionic adjuvant that has been widely tested with various herbicides. However, its performance with lactofen for controlling $R$. capitata in green gram still needs to be assessed. A study was consequently planned to estimate the activity of lactofen at full and minimized doses on $R$. capitata in green gram with addition and without addition of alkyl ether sulphate as adjuvant.

\section{Materials and Methods}

A trial was executed to assess the activity of lactofen at its recommended and minimized application rate against Rbynchosia capitata (Roth.) DC in green gram (Vigna radiata L.) alone and in tank mixed combination of adjuvant (alkyl ether sulfate) at Research Area, College of Agriculture, University of Sargodha during the spring 2015.

\section{Plant material and growth conditions}

Mature pods from more than 500 plants of $R$. capitata were collected from green gram crop fields in district Layyah of Southern Punjab, Pakistan (30 $57^{\prime}$ N, 70 $56^{\prime}$ E). Seeds were removed from the pods, separated from inert matter, organized for uniform size and then stored for 4 to 5 months at room temperature before using for sowing in experiment. Germination of $R$. capitata may be delayed due to its hard seed coat. To enable the germination, the seeds were rubbed on wood sand paper (No. 80) from the opposite surface of embryo till cotyledon exposure. Ten seeds each of green gram (var. $A Z R I-2006)$ and $R$. capitata were sown in pots ( $24 \mathrm{~cm}$ diameter) filled with sandy loam soil at proper moisture level on March 25, 2015. One week after emergence, green gram and $R$. capitata seedlings were thinned to 5 plants per pot. Irrigations were applied frequently in equal quantity to each pot according to crop requirement till physiological maturity.

\section{Experimentation}

Six herbicide treatments, viz. lactofen recommended application rate (at $180 \mathrm{~g}$ a.i. $\mathrm{ha}^{-1}$ ) alone, lactofen 60\% (at $108 \mathrm{~g}$ a.i. ha ${ }^{-1}$ ) and 80\% (at $144 \mathrm{~g}$ a.i. ha ${ }^{-1}$ ) of recommended rate, lactofen recommended rate with adjuvant (alkyl ether sulphate), and lactofen $60 \%$ and $80 \%$ of recommended rate with adjuvant were applied as foliar spray at 2-4 leaf stage (10 days 
of emergence) of $R$. capitata. For herbicides spray, a Knapsack hand sprayer at $207 \mathrm{KPa}$ pressure having T-Jet nozzle was used. A control with no herbicide spray was kept for comparison. Pots were arranged in completely randomized design (CRD) with four replications.

\section{Data collection and statistical analysis}

The data concerning various weed growth parameters such as weed density per pot (after 21 days of herbicide treatment), weed fresh weight and dry weight at harvest, weed control efficiency and herbicide efficiency index; and mung bean growth and yield parameter such as plant height, number of pod bearing branches per plant, seeds per pod, 1000-seed weight, seed yield, biological yield, and harvest index (\%) were recorded using their standard procedures. Based on the weed dry weight reduction from control, weed control efficiency was calculated using the formula as described by Gupta (1998):

$$
\text { Weed Control Efficiency }=\frac{W 1-W 2}{W 1} \times 100
$$

Where,

W1 = Dry matter of weeds in control pots; W2 = Dry matter of weeds in treated pots.

Herbicide efficiency index of each treatment was calculated by using the formula given by Walia (2003) as follow:
Where;

$\mathrm{YT}=$ Green gram seed yields of treated plots; $\mathrm{YC}=$ Green gram seed yields of control plots; DMT= weed dry matter in treatment plots; DMC= weed dry matter in control plots.

For statistical analysis of experimental data, the analysis of variance technique as suggested by Fisher (Steel et al., 1997) was employed and for means' comparison, Tukey's honestly significant difference (HSD) test was used keeping in view 5\% probability level.

\section{Results and Discussion}

\section{Weed growth}

Data regarding $R$. capitata weed density, fresh and dry weights are presented in Table 1 which revealed that treatment of lactofen herbicide caused significant reduction in these parameters compared with weedy check. Lactofen full application rate along with adjuvant produced maximum phytotoxic effect in $R$. capitata as this treatment showed the lowest density ( 3 plants pot $\left.^{-1}\right)$ and dry weight $\left(3.18 \mathrm{~g} \mathrm{pot}^{-1}\right)$ of this weed as recorded 21 days after treatment and at crop harvest, respectively. However, this treatment was statistically at par with lactofen full application rate without alkyl ether sulfate and lactofen 80\% dose along with alkyl ether sulfate regarding these parameters.

$$
H E I=\frac{Y T-Y C}{Y C} / \frac{D M T}{D M C} \times 100
$$

Table 1: Density and growth parameters of $R$. capitata weed as influenced by different lactofen herbicide treatments.

Treatments

\section{R. capitata growth parameters}

Weed density pot $^{-1} 21$ days after Fresh weight $\left(\mathrm{g} \mathrm{pot}^{-1}\right)$ at treatment

Control (no herbicide spray)

$5.00 \mathrm{a}$

Lactofen at $180 \mathrm{~g}$ a.i. $\mathrm{ha}^{-1}$

$3.25 \mathrm{c}$

(complete dose)

Lactofen $80 \%$ dose

$4.50 \mathrm{ab}$

$4.75 \mathrm{a}$

Lactofen complete dose + alkyl ether $\quad 3.00 \mathrm{c}$ sulphate

Lactofen $80 \%$ dose + alkyl ether sulphate 3.50 bc

Lactofen $60 \%$ dose + alkyl ether sulphate 4.75 a

HSD harvest

$47.8 \mathrm{a}$

$24.4 \mathrm{c}$

$31.7 \mathrm{~b}$

$33.4 \mathrm{~b}$

$20.4 \mathrm{~d}$

$23.5 \mathrm{~cd}$

$31.6 \mathrm{~b}$

3.77
$3.81 \mathrm{~cd}$

dry weight $\left(\mathrm{g} \mathrm{pot}^{-1}\right)$ at harvest

$9.81 \mathrm{a}$

$3.31 \mathrm{~d}$

$4.87 \mathrm{bc}$

$5.37 \mathrm{~b}$

$3.18 \mathrm{~d}$

$5.00 \mathrm{bc}$

1.285

Figures sharing same letter(s) in a column do not differ significantly at 5\% probability. HSD: Tukey's honestly significant difference.

December 2021 | Volume 34 | Issue 4 | Page 708 
The decrease in $R$. capitata weed density and biomass to various degrees by different lactofen herbicide treatments was attributed to their phytotoxic action against this weed. Our findings are in line with those of Windley et al. (1999) who noted that herbicides not only reduced the density of Trianthema portulacastrum and Macroptilium lathyroides, but also increased green gram yield. Tanveer et al. (2003) concluded that weed fresh weight was expressively reduced by the herbicide application. These consequences are also similar with the results of Javaid (2012) who reported that with the spray of Bromoxynil + MCPA, 100\% control of Emex spinosa was observed. Alkyl ether sulfate usually enhanced the efficiency of tribenuronmethyl with reduced rate when applied at vegetative stages. Our results are similar with the findings of Javaid et al. (2012) who demonstrated that adjuvants along with reduction in doses of carfentrazone-ethyl and fluroxypyr + MCPA herbicides also improved the efficacy of herbicides that resulted in $100 \%$ mortality and reduced biomass of E. spinosa.

Comparison of weed control efficiency and herbicide efficiency index of different lactofen herbicide treatments has been depicted in Figures 1 and 2, respectively. An overlook of data given in Figures 1 and 2 indicated that the highest weed control efficiency (65\%) and herbicide efficiency index (2.6) were shown by the lactofen full dose along with alkyl ether sulfate adjuvant. Whereas lactofen full dose without adjuvant and lactofen $80 \%$ dose with adjuvant remained at second and third position in this regard. The $R$. capitata dry weight variation recorded due to the application of different lactofen herbicide doses alone and in combination with adjuvant was probably due to their differential phyto-inhibitory action against this weed. These results are in accordance with results of Ali et al. (2003) who reported that low dry weight was recorded from the pots that are treated with herbicide as compared to weedy check pots. Similar findings were also documented by Everman et al. (2007) and Richardson et al. (2007) who reported that in cotton crop by the herbicide application, the dry weight of $T$. portulacastrum was reduced significantly.

\section{Crop growth and seed yield}

Data related to growth, yield and yield components as affected by different lactofen herbicide treatments are presented in Table 2. A perusal of data indicated that all herbicide treatments gave significant increase in plant height of green gram in comparison with control treatment receiving no herbicide spray. Among herbicide treatments, the highest plant height $(43 \mathrm{~cm})$ of green gram was noted with lactofen full dose along with alkyl ether sulfate as adjuvant. However, this treatment remained statistically at par with lactofen full dose and lactofen $80 \%$ dose alone and with adjuvant regarding plant height of green gram. The increase in plant height of green gram by herbicide treatments could be the result of better vegetative growth of the crop due to better $R$. capitata control that otherwise might utilize environmental resources at the expense of poor crop growth.

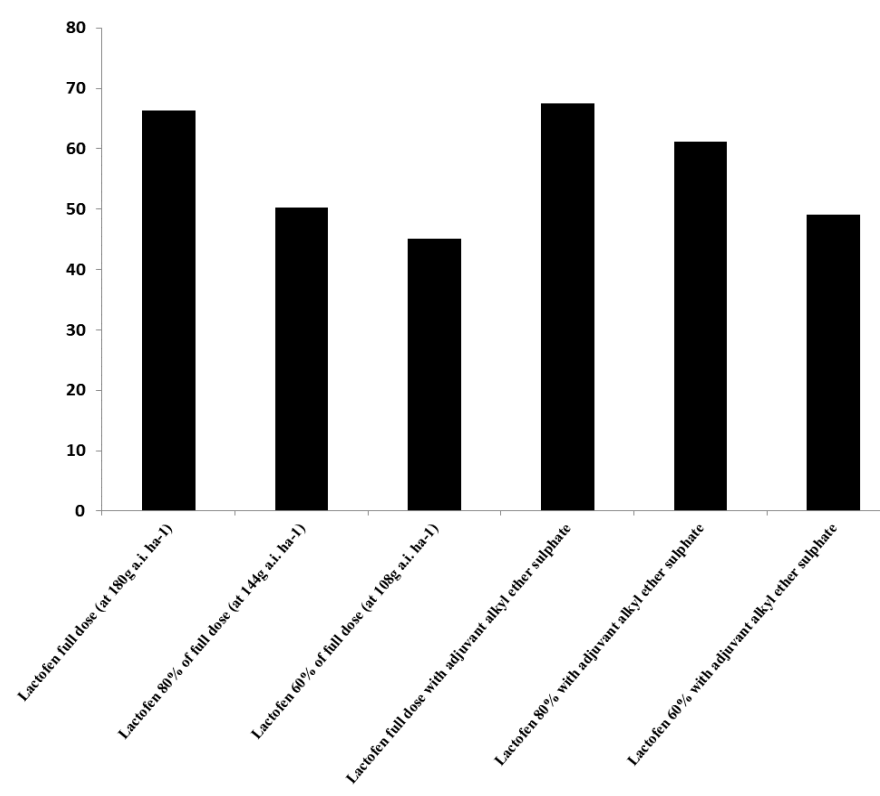

Figure 1: Weed control efficiency of lactofen as affected by alkyl ether sulphate adjuvant.

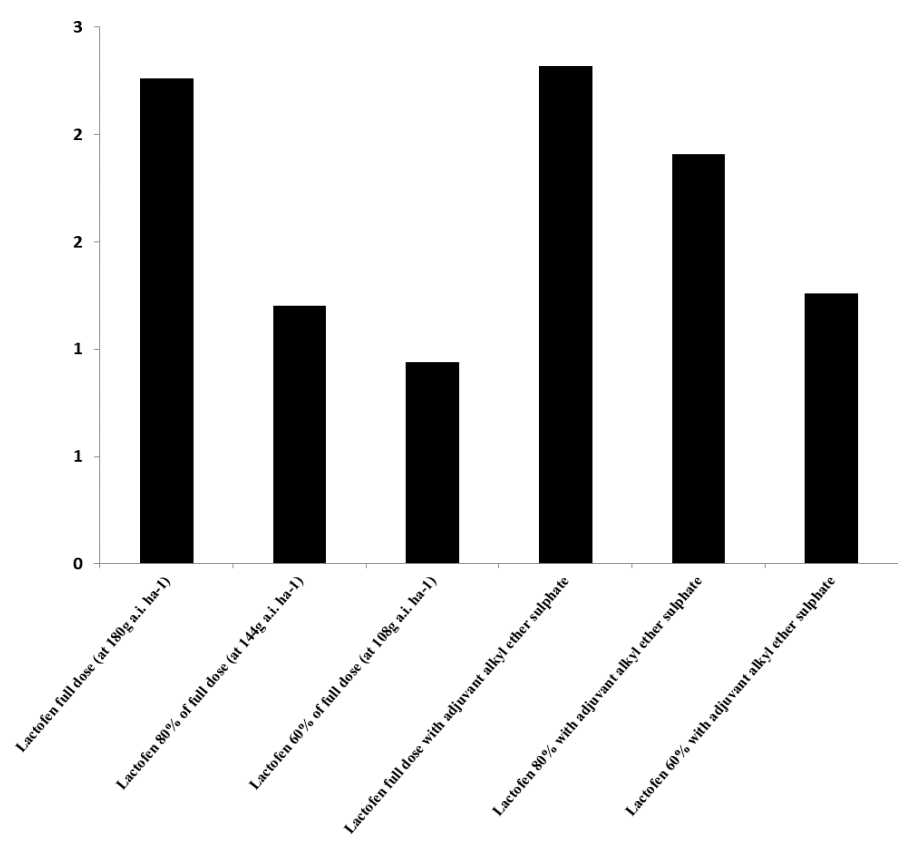

Figure 2: Herbicide efficiency index of lactofen as affected by alkyl ether sulphate adjuvant. 
Table 2: Growth and yield of green gram as influenced by different lactofen herbicide treatments.

\begin{tabular}{|c|c|c|c|c|c|c|c|}
\hline Treatments & $\begin{array}{l}\text { Plant } \\
\text { height } \\
\text { (cm) }\end{array}$ & $\begin{array}{l}\text { Pods } \\
\text { per } \\
\text { plant }\end{array}$ & $\begin{array}{l}\text { Seeds } \\
\text { pod }^{-1}\end{array}$ & $\begin{array}{l}\text { 1000-seed } \\
\text { weight }(\mathrm{g})\end{array}$ & $\begin{array}{l}\text { Biological } \\
\text { Yield (kg } \\
\text { ha }^{-1} \text { ) }\end{array}$ & $\begin{array}{l}\text { Seed Yield } \\
\left(\mathrm{kg} \mathrm{ha}^{-1}\right)\end{array}$ & $\begin{array}{l}\text { Harvest } \\
\text { index } \\
(\%)\end{array}$ \\
\hline Control (no herbicide spray) & $31.5 \mathrm{~d}$ & $12.4 \mathrm{ab}$ & $7.06 \mathrm{bc}$ & $21.8 \mathrm{c}$ & $2414.7 \mathrm{~d}$ & $481.3 \mathrm{~d}$ & $19.9 \mathrm{ab}$ \\
\hline Lactofen at $180 \mathrm{~g}$ a.i. ha ${ }^{-1}$ (complete dose) & $40.8 \mathrm{abc}$ & $13.7 \mathrm{ab}$ & $9.12 \mathrm{ab}$ & $29.7 \mathrm{ab}$ & $4366.4 \mathrm{a}$ & 848.7 a & $19.4 \mathrm{~b}$ \\
\hline Lactofen $80 \%$ dose & $41.0 \mathrm{abc}$ & $12.2 \mathrm{~b}$ & $8.50 \mathrm{abc}$ & $26.5 \mathrm{~b}$ & $3881.6 \mathrm{~b}$ & $769.3 \mathrm{bc}$ & $19.8 \mathrm{ab}$ \\
\hline Lactofen $60 \%$ dose & $39.0 \mathrm{c}$ & $12.0 \mathrm{~b}$ & $6.50 \mathrm{c}$ & $25.4 \mathrm{bc}$ & $3411.4 \mathrm{c}$ & $728.9 \mathrm{c}$ & $21.3 \mathrm{a}$ \\
\hline Lactofen complete dose + alkyl ether sulphate & $43.0 \mathrm{a}$ & $14.2 \mathrm{a}$ & $9.44 \mathrm{a}$ & $32.6 \mathrm{a}$ & $4240.5 \mathrm{a}$ & $844.2 \mathrm{a}$ & $19.9 \mathrm{ab}$ \\
\hline Lactofen $80 \%$ dose + alkyl ether sulphate & $41.8 \mathrm{ab}$ & $13.2 \mathrm{ab}$ & $8.50 \mathrm{abc}$ & $29.5 \mathrm{ab}$ & $4361.3 \mathrm{a}$ & $837.8 \mathrm{ab}$ & $19.2 \mathrm{~b}$ \\
\hline Lactofen $60 \%$ dose + alkyl ether sulphate & $39.9 \mathrm{bc}$ & $12.0 \mathrm{~b}$ & $7.25 \mathrm{bc}$ & $25.9 \mathrm{bc}$ & $3603.2 \mathrm{c}$ & $790.3 \mathrm{abc}$ & $21.5 \mathrm{a}$ \\
\hline HSD & 2.48 & 1.83 & 2.1 & 4.51 & 227.3 & 71.3 & 1.91 \\
\hline
\end{tabular}

Figures sharing same letter(s) in a column do not differ significantly at 5\% probability. HSD: Tukey's bonestly significant difference.

All herbicide treatments could not cause significant increase in number of pods per plant and harvest index of green gram compared with non-treated control. However, significant enhancement from control was observed in seeds per pod (9.44) of green gram only by applying lactofen full dose along with alkyl ether sulfate adjuvant. Regarding 1000-seed weight of green gram, lactofen full dose along with adjuvant performed the best by attaining the highest 1000-seed weight (32.6 g). However, this treatment remained statistically similar to lactofen full dose without adjuvant and lactofen $80 \%$ dose with adjuvant regarding this yield component. The improvement in the number and weight of green gram seeds in plants harvested from pots treated with herbicide was probably due to reduced competitive stress by $R$. capitata during reproductive growth phase of green gram that resulted in its better seed production and seed development (Borras et al., 2004). Singh et al. (1996) showed 40\% reduction in number of seeds pods ${ }^{1}$ of green gram due to the crop-weed competitions. The enhancement in 1000-grain weight of wheat in herbicide treated plots as a consequence of reduced weed infestation was also mentioned by Cheema and Akther (2005). Singh et al. (1996) calculated a reduction of up to $44 \%$ in 1000 -seed weight of green gram due to presence of weeds.

The biological and seed yields, the resultants of all the underlying growth and yield components showed significant increase by applying all lactofen herbicide treatments in comparison with control. However, significantly the highest biological yield (43664.4 $\mathrm{kg} \mathrm{ha} \mathrm{a}^{-1}$ ) of green gram was achieved with lactofen full dose alone that did not differ significantly from lactofen full dose along with adjuvant and lactofen $80 \%$ dose with adjuvant. It seem to be due to effective weed control in these treatments that minimized $R$. capitata competition stress in green gram thereby enhancing its plant height and number of pods compared to that observed with control pots. These plant traits participated in increased biological yield of green gram. These consequences are in accordance with the observations of Chattha et al. (2007) who reported that by the applications of herbicides, biomass of green gram was enhanced as compared to the control pots or weedy check.

Seed yield is the final goal of producers and most imperative parameter which depends upon yield contributing traits i.e. number of pods plant $^{-1}, 1000$ seed weight and seeds pod $^{-1}$. The best performance in terms of seed yield of green gram was shown by lactofen full dose alone, lactofen full dose with adjuvant, and lactofen $80 \%$ and $60 \%$ doses with adjuvant by producing $848.7,844.2,837.8$ and 790.3 $\mathrm{kg} \mathrm{ha}{ }^{-1}$ seed yields of green gram. The increment in seed yield of green gram by these herbicide treatments seems to be due to increase in number of seeds per pod and 1000-seed weight in these treatments. Our results are in line with the findings of Cheema et al. (2000) and Chattha et al. (2007). Windley et al. (1999) found increased green gram seed yield in herbicide treated plots on account of better $T$. portulacastrum and Macroptilium lathyroides weeds control. Weedcrop competitions were reduced by the herbicides applications resultantly increasing the crop yield. Mitra and Bhattacharya (2005) also documented that the application of butachlor resulted in higher green gram biomass, yield components, seed yield.

\section{Conclusions and Recommendations}

Lactofen dose can be reduced up to $20-40 \%$ by the 
addition of alkyl ether sulphate as adjuvant for the cost-effective and eco-friendly management of $R$. capitata in $V$. radiata crop.

\section{Acknowledgements}

This paper is based upon research conducted during MSc (Hons.) Agriculture and derived from thesis submitted during March, 2016.

\section{Novelty Statement}

Rhynchosia capitata (Roth.) DC is an invasive weed in Pakistan. Its effective control in green gram is discovered with low herbicide dose with the addition of alkyl ether sulfate adjuvant.

\section{Author's Contribution}

Muhammad Ehsan Safdar: Overall Management of the article and Technical Input at every step.

Samra Ammara: Collected data and Methodology.

Muhammad Sikander Hayyat: Wrote abstract.

Shahbaz Hussain: Wrote result and discussion, Introduction and References.

Muhammad Mansoor Javaid: Conceived the idea.

Abdul Rehman: Conclusion.

Amjed Ali: Did SPSS analysis.

\section{Conflict of interest}

The authors have declared no conflict of interest.

\section{References}

Ali, H.H., A. Tanveer, M.A. Nadeem and H.N. Asghar. 2011. Methods to break seed dormancy of Rhynchosia capitata, a summer annual weed. Chil. J. Agric. Res., 71(3): 483-487. https://doi. org/10.4067/S0718-58392011000300021

Ali, R., S.K. Khalil, S.M. Raza and H. Khan. 2003. Effect of herbicides and row spacing on maize (Zea mays L.). Pak. J. Weed Sci. Res., 9(3-4): 171-178.

Arshad, M., M. Aslam, M. Irshad and M. Sharif. 2008. AZRI mung-2006: A high yielding short duration and bold seeded mungbean variety. J. Agric. Res., 46(3): 299-307.

Borras, L., G.A. Slafer and M.E. Otegui. 2004. Seed dry weight response to source sink manipulations in wheat, maize and soybean: A quantitative reappraisal. Field Crop Res.,
86: 131-146. https://doi.org/10.1016/j. fcr.2003.08.002

Chattha,M.R., M.Jamil and T.Z.Mahmood. 2007. Yield and yield components of mungbean as affected by various weed control methods under rain-fed conditions of Pakistan. Int. J. Agric. Biol., 9(1): 114-119.

Cheema, M.S. and M. Akther. 2005. Efficacy of different post emergence herbicides and their application methods in controlling weeds in wheat. Pak. J. Weed Sci. Res., 11: 23-30.

Cheema, Z.A., A. Rakha and A. Khaliq. 2000. Use of sorgaab and sorghum mulch for weed management in mungbean. Pak. J. Agric. Sci., 37: 140-144.

Dungarwal, H.S., P. Chaplot and B.L. Nagda. 2003. Chemical weed control in mungbean (Phaseolus radiatus L.). Indian J. Weed Sci., 35: 283-84.

Everman, W.J., I.C. Burke, J.R. Allen, J. Collins and J.W.Wilcut. 2007. Weed control and yield with glufosinate-resistant cotton weed management systems. Weed Technol., 21(3): 695-701. https://doi.org/10.1614/WT-06-164.1

Government of Pakistan, 2020. Economic survey of Pakistan. Finance and Economic Affairs Division, Islamabad: pp. 22-23.

Gupta, O.P., 1998. Weed management: Principles and practices. Agro Botanica, Bikaner, India.

Hess, F.D. and C.L. Foy. 2000. Interaction of surfactants with plant cuticles. Weed Technol., 14: 807-813. https://doi.org/10.1614/0890037X(2000)014[0807:IOSWPC]2.0.CO;2

Hess, F.D., 2000. Light-dependent herbicides: An overview. Weed Sci., 48: 160-170. https://doi. org/10.1614/0043-1745(2000)048[0160:LDH $\mathrm{AO}] 2.0 . \mathrm{CO} ; 2$

Javaid,M.M.,2012. Studies on ecology,competition and control of two Emex Species (Emex australis and Emex spinosa) in wheat (Triticum aestivum L.). $\mathrm{PhD}$ thesis, University of Agriculture, Faisalabad.

Javaid, M.M., A. Tanveer, R. Ahmad, M. Yaseen and A. Khaliq. 2012. Optimizing activity of herbicides at reduced rate on Emex spinosa with adjuvants. Plant. Daninha, 30(2): 425-435. https://doi.org/10.1590/S010083582012000200023

Lehnen, L.P., T.D. Sherman, J.M. Becerril and S.O. Duke. 1990. Tissue and cellular localization of acifluorfen-induced porphyrins in cucumber cotyledons. Pestic. Biochem. Physiol., 37: 
239-248. https://doi.org/10.1016/00483575(90)90130-T

Mansoor, M., H.K. Ahmad, H. Khan and M. Yaqoob. 2004. Development of economical weed management strategies for mungbean (Vigna radiata L. Wilczek.). Pak. J. Weed Sci. Res., 10(3-4): 151-156.

Matringe, M., J.M. Camadro, P. Labbe and R. Scalla. 1989. Protoporphyrinogen oxidase as a molecular target for diphenyl ether herbicides. Biochem. J., 260: 231-235. https://doi. org/10.1042/bj2600231

Mitra, S. and B.K. Bhattacharya. 2005. Water use and productivity of green gram (Vigna radiata) as influenced by spacing, mulching and weed control under rain-fed upland situation of Tripura. Indian J. Agric. Sci., 75: 52-54.

Naeem, M., H. Ali and S. Ahmad. 1999. Effect of pre-plant and pre-emergence herbicides on weed growth and nodulation of mungbean. Pak. J. Biol. Sci., 2: 1598-1600. https://doi. org/10.3923/pjbs.1999.1598.1600

Radosevich, S.R., J.S. Holt and C.M. Ghersa. 2007. Ecology of weeds and invasive plants: Relationship to agriculture and natural resource management, $3^{\text {rd }}$ edition. John Wiley and Sons, Inc. Hoboken, New Jersey, USA. https://doi. org/10.1002/9780470168943

Richardson, R.J., H.P. Wilson and T.E. Hines.
2007. Pre-emergence herbicides followed by trifloxysulfuron post-emergence in cotton. Weed Technol., 21(1): 1-6. https://doi. org/10.1614/WT-05-047.1

Sharma, N.K., M.M. Sharma and D.N. Sen. 1978. Seed perpetuation in Rhynchosia capitata DC. Biol. Plant., 20(3): 225-228.

Singh, A., S. Singh and V.M. Bhan. 1996. Crop weed competition in summer green gram. Indian J. Agron., 14(4): 616-619.

Steel, R.G.D., J.H. Torrie and D.A. Dickey. 1997. Principles and procedures of statistics. A biometrical approach $3^{\text {rd }}$ Ed. McGraw Hill Book Co., Inc., Singapore.

Tanveer, A., N.H. Chaudhry, M. Ayub and R. Ahmad. 2003. Effect of cultural and chemical weed control methods on weed population and yield of cotton. Pak. J. Bot., 35(2): 161-166.

Ullah, A., T.M. Shah and M. Farooq. 2020. Pulses Production in Pakistan: status, constraints and opportunities. Int. J. Plant Prod., 6: 1-21.

Walia, U.S., 2003. Principles of weed research experiments. In: Weed Management, Kalyani Publishers, New Delhi, India, pp. 334-350.

Windley, E., D. White, L. Redinan and S. Short. 1999. Screening broadleaf herbicides for post emergent use in mungbean. ACIAR Food Legume Newsl., 30: 8-11. 